
battery, the strength of the current is reduced rather more than by the
introduction of a simple wire of the same resistance as the pile. Account for this effect.

8. A gold flig globe of six inches' radius is filled with water. Determine the apparent position of a point inside the globe, 4 inches from its surface, when seen by an eye outside looking along a radius of the globe.

8. Trace the changes in the position and size of the virtual image formed by concave lens when the object moves from an infinite distance up to the lens. Explain how the image is formed by the concave eje-piece of an opera-glass.

Besides being extraordinarily difficult aud pedantically framed, they deal with departments of natural philosophy far removed from the requirements of future medical men. They might be fit for an advanced class of civil, mechanical, or electrical engineers, devoting all their time and energies to mathematical physics; for young men still under age, who have to get up zoology, botany, and chemistry simultaneously, they are simply disgraceful. It is, therefore, not surprising that, as Dr. Bristowe, himself a distinguished student of the University, has shown, of a hundred who begin this career only ten succeed in completing it. It is also unfortunately obvious that where such recondite and uncommon questions are asked, there must be, even with the greatest care, an advantage given unintentionally to pupils attending the classes of examiners who are themselves teachers.

August 4th, 1884. I am, Sir, yours, \&c.

WILLIAM H. STONE Censor, Royal College of Physicians.

\section{HEALING OF WOUNDS IN THE SOUDAN.}

\section{To the Editor of THE LANCET.}

SrR,-I have had under my care at the Egyptian Military Hospital, Suakin, for fifty-seven days, three men whose right hands were amputated by order of Osman Digma forty-five days before they came under my charge. During these forty-five days they were kept prisoners in chains at Osman's camp at Tamanieb, their wounds being quite unattended to. they themselves having torn a piece off their scanty cloth to wrap round the stumps. When freed, they made their way direct to Suakin and appeared at the hospital for treatment.

As may be imagined, the dressing was in a rather filthy state, but I was surprised to find that active and healthy granulation was going on, with small discharge and no pain, the bones being quite covered by granulations, the stumps large, and healthy ulcers with small healing edges, which after a few days' dressing in hospital grew over the granulations with great vigour. At present the stumps are perfectly rounded, and with a very slight scar where the last of the dermis covered the granulations.

It may interest some of your readers to know how Osman performs his amputations. The right hand of the unfortunate "friendly" was grasped by one man, whilst another tied round the forearm a rope so tightly as to stop the circulation. This rope was dragged upon in one direction, the hand in the opposite. A third operator with one of the ordinary Soudanese curved knives made a circular incision round the wrist over the radio-carpal joint, and so between dragging and cutting the hand was separated from the arm. The method of preventing hæmorrhage was as follows. Befure the cord on the arm was loosed, a pot of tallow was placed over a charcoal fire, the men operated on squatting in the usual Eastern fashion till the tallow bolled, then one by one their stumps were thrust into the boiling tallow and kept there till danger of hæmorrhage was supposed to be over. Afterwards they were kept in irons till the day before they appeared in Suakin.

I cite other two cases which have come under my care here.

1. An Abyssinian boy, sixteen years of age, who was in General Baker's battle of Teb, was retreating with the other Abyssinians engaged there, when he was struck by a spear over the superior border of and close to the right scapula, the spear penetrating in a downward direction, and the point making its exit below the clavicle at the junction of the middle and outer third. After receiving the wound the boy assisted in killing the man who struck him, and ran seven miles-i,e., to the harbour of Tokar; he was then shipped to Suakin. The spear measured from $1 \frac{1}{2}$ in. wide at its tip to 2 in. at its base, and from $\frac{1}{4}$ in. to $\frac{1}{2}$ in. thick in its central rib. No important bloodvessels were injured, no nerve cords were much hurt, and not a bad symptom appeared in the wound, which was quite healed in six weeks. Fur two or three weeks afterwards he had slight pain in the course of the musculo-spiral nerve, which quite disappeared.

2. An Abyssinian was shot at the battle of Tamar, the ball passing through the upper part of his thigh close behind the femur, then through the serotum without injuring the testicles or cords. He was walking about in hospital in the three weeks.

I believe all these cases are examples of the rapid and certain healing of wounds so often seen here in natives of the Soudan and Abyssinia. Many other cases have come under my notice. In no cases have I seen suppuration, except in those where no precautions have been taken to keep the wounds clean, and the Listerian antiseptic system is not carried out by me. Abstinence from alcoholic liquors and simple feeding might be said to explain the sure healing of the wound s of the Soudanese, but not of the Abyssinians, who drink whenever opportunity occurs, and eat as much butchers meat as they can afford, and on special occasions without cooking it. The dressings used in all the cases cited were simply carbolic water, lint, and gutta-percha tissue; over that a compress of cotton cloth and a bandage.

I am, Sir, yours truly,

Suakin, July 26th, 1884

Alex. Galbraith, M.B. Surgeon-Major, E.A.

\section{THE ANCOATS MURDER CASE.}

\section{To the Editor of THE LANCET.}

SIR, -Since the issue of last week's LANCET, in whick you make some comments in a leading article on what has been called the Ancoats murder, 1 my attention has been directed to certain facts connected with the case. It appears that the accused man, Donnelly, was, eighteen months ago, a patient of mine at the Hospital for Epilepsy and Paralysis, suffering from a severe form of epilepsy, accompanied with serious attacks of temporary mental derangement. At that time the patient stated that under the influence of his complaint he had frequently committed assaults and other crimes, for which he had been arrested, and even wrongly punished by imprisonment. While in the hospital, on several occasions he performed acts of violence obviously under insane impulses, and of which he was afterwards totally unconscious, He was finally discharged unrelieved, and considered as incurable. Although it was obvious at the time that this individual should have been placed under some kind of restraint, the law does not recognise the necessity of interfering with the liberty of the subject under such circumstances. Accordingly, after years of minor misdemeanours against society, it is only after murder and homicidal assault have been perpetrated-a sister havin been killed and a mother mutilated-that the actor in al these offences has received the official attention which his case has so long merited. Furthermore, this unfortunate wretch, having at last been arraigned before a jury of his countrymen, has been compelled to undergo the mental torture not only of being tried for the most awful crime of which a man can be accused, but of being pronounced guilty of wilful murder, and actually sentenced to death as a male factor of the most brutal and unnatural type. That this egal judgment has since been partially remitted will be little consolation to the accused or his family, after all the agonies of mind they must have endured.

I quite agree with your editorial remarks that the essential facts connected with an important criminal inquiry should be elicited at the trial, and not after the accused has beet condemned to death as a murderer, and my object in addressing this letter to you is to express the opinion that in this case the disastrous uncertainty might have been entirely avoided had the matter been properly investigated at that time. There seems, in short, to have been an oversight on the part of the defence in failing to ascertain the ordinary circumstances in behalf of the prisoner. He had been patient of Dr. Dreschfeld of Manchester, who doubtless could have testified to his condition. He was under my own observation for some months, I possess fall notes of his case, and could have strongly advocated his irresponsibility. Although the authorities were duly informed that the accused had been an inmate of at least two public hospitals, no efforts were made to utilise this evidence in his favour and no medical man was called upon to prove his mental condition. Those, in short, who could have placed the whole matter in such a light as would have convinced any jury 